\title{
Experimental Study on Fiber Reinforced Green Concrete for M-30 Grade
}

\author{
Saranya .Valivarthi ${ }^{1}$, M.Durga Rao ${ }^{2}$ \\ ${ }^{I} M$.TECH, Department of CE, MVRCET,Vijayawada,Paritala. \\ ${ }^{2}$ ASSISTANT PROFESSOR, Department of Civil Engineering, Mvrcet.
}

\begin{abstract}
This paper deals with the concrete made of wastes which are ecofriendly so called as green concrete. To study the compressive strength, tensile strength of fibre reinforced green concrete (FRGC) containing fibers of $0.71 \%$ and with different percentages of stone dust, marble sludge we are using $M$-30 grade of concrete having mix proportion 1:1.92:2.76 with water cement ratio 0.41. The result data obtained has been analyzed and compared with a control specimen (0\% fiber). A relationship between compressive strength and flexural strength is represented graphically. Result shows the percentage increase in 28 days Compressive strength, Flexural strength for M-30 Grade of Concrete.
\end{abstract}

Keywords: Bamboo, Stone dust, Marble sludge,

\section{Introduction}

Green concrete is an revolutionary topic in the history of concrete industry. It is capable for the development that is characterized by application of industrial wastes to reduce consumption of natural resources and energy and pollution of the environment. Marble sludge powder can be used as filler and helps to reduce the total voids content in concrete. Natural sand in many parts of the country is not graded properly and has excessive silt on other hand quarry rock dust does not contain silt or organic impurities and can be produced to meet desired gradation and fineness as per requirement. This contributes to improve the strength of concrete Through this reaction with the concrete admixture, marble sludge powder and stone dust improved pozzolanic reaction, micro-aggregate filling, and concrete durability. This paper presents the feasibility of the usage of stone dust and marble sludge powder as hundred percent substitutes for natural sand in concrete added fiber as reinforcement as it improves the tensile strength of concrete. An attempt has been made to durability studies on green concrete compared with natural sand concrete .It is found that the compressive, split tensile strength and durability studies of concrete made of stone dust are nearly $14 \%$ more than the conventional concrete. The concrete resistance to sulphate attack was enhanced greatly.

\subsection{Materials used}

\section{Experimental Programme}

\section{RAW MATERIALS:}

CEMENT: Ordinary Portland Cement (53 Grade)) with 29_percent normal consistency with specific surface $3300 \mathrm{~cm} 2 / \mathrm{g}$ conforming to IS: $8112-1989$ was used.

MARBLE SLUDGE POWDER: Marble sludge powder was obtained in wet form directly taken from deposits of marble factories. It was observed that the marble sludge powder had a high specific surface area; this could mean that is addition should confer more cohesiveness to mortars and concrete. Specific gravity of the marble sludge powder is 2.212 .

QUARRY ROCK DUST: The specific gravity of the quarry rock dust is 2.667. Moisture content and bulk density of waste are less than the sand properties.

FINE AGGREGATE: Medium size sand with a finess modulus $=2.20$; Specific gravity 2.677 , normal grading with the silt content $0.8 \%$.

COARSE AGGREGATE: Crushed stone with a size of 5-20 mm and normal continuous grading. The content of flaky and elongated particles is $<3 \%$, the crushing index $\leq 6 \%$ and the and the specific gravity 2.738

WATER: The qualities of water samples are uniform and potable.

SUPER PLASTICIZER: A super plasticizer based on refined lingo Sulphonates, _Roff Superplast 320 was used to get desired workability. 


\section{B) SPECIFIC GRAVITY:}

- The specific gravity of solid particles is the ratio of the mass density of solids to that of standard fluid. It is determined in the laboratory using the relation.

G = (M2-M1)/ (M4-M1)- (M3-M2)

Where, M1 = Mass of empty Density Bottle

M2 = Mass of Bottle and Cement

M3 = Mass of bottle, cement $\&$ kerosene

M4 = Mass of bottle with kerosene

$\mathrm{M} 1=34 \mathrm{Gms}$

$\mathrm{M} 2=83 \mathrm{Gms}$

$\mathrm{M} 3=114 \mathrm{Gms}$

$\mathrm{M} 4=80 \mathrm{Gms}$

Specific Gravity of cement $=3.15$

C) INITIAL SETTING TIME:

- The initial setting of the cement is 90 minutes.

D) NORMAL CONSISTENCY

- Usually standard consistency lies between 26 to $33 \%$.

- Normal consistency is $29 \%$.

THE PHYSICAL CHARACTERISTICS OF MARBLE SLUDGE POWDER AND ROCK DUST:

\begin{tabular}{|l|l|l|l|l|l|l|l|}
\hline Sample Code & wet & Dry & Bulk density & Fineness modulus & Effective size & Coeff.of uniformity & Coeff.of Gradation \\
\hline $\begin{array}{l}\text { Marble sludge } \\
\text { Powder }\end{array}$ & 23.35 & 1.59 & 1118 & 2.04 & .17 & 1.58 & 1.37 \\
\hline $\begin{array}{l}\text { Quarry rock } \\
\text { Dust }\end{array}$ & 24.25 & 2.10 & 1750 & 2.35 & .22 & 4.50 & 2.20 \\
\hline River sand & 25.00 & 2.50 & 1430 & 2.20 & .20 & 6.00 & 2.00 \\
\hline
\end{tabular}

\section{DESIGN:}

\section{CASTING AND TESTING OF CONCRETE}

Cubes and beams were casted by replacing the fine aggregate with quarry rock dust and marble sludge powder with different proportions. A total of 24 cubes and 8 beams were casted i.e; 3 cubes and 1 beam for each proportion and reinforced with bamboo fibre to get more tensile strength.

The proportions are:

1. normal concrete $+100 \%$ stone dust

2. normal concrete $+100 \%$ marble sludge

3. normal concrete $+50 \%$ stone dust $+50 \%$ marble sludge

4. normal concrete $+30 \%$ stone dust $+70 \%$ marble sludge

5. normal concrete $+100 \%$ stone dust $+0.71 \%$ fibre

6. normal concrete $+100 \%$ marble sludge $+0.71 \%$ fibre

7. normal concrete $+50 \%$ stone dust $+50 \%$ marble sludge $+0.71 \%$ fibre

8. normal concrete $+30 \%$ stone dust $+70 \%$ marble sludge $+0.71 \%$ fibre

\section{A) DESIGN STIPULATIONS FOR PROPORTIONING:}

a. Grade designation: M30

b. Type of cement: OPC 53 grade, IS 8112

c. Max. Nominal size of agg. : $20 \mathrm{~mm}$

d. Minimum cement content: $\underline{300}(320) \mathrm{kg} / \mathrm{m}^{3}$

e. Maximum water cement ratio : 0.45

f. Workability: 75-100 mm (slump)

g. Exposure condition: severe

h. Degree of supervision: Good

i. Type of agg. : Crushed angular agg.

j.Maximum cement content: $450 \mathrm{~kg} / \mathrm{m} 3$

k. Method of concrete placing: pumping

B) TEST DATA FOR MATERIALS

a. Cement used : OPC 53 grade

b. Specific gravity of cement : 3.15 
c. Specific Gravity of marble sludge: 2.212

d. Specific gravity of rock dust : 2.667

e. Sieve analysis

f. Coarse aggregate : Conforming to Table 2 of IS 383

Test results:

The compressive strength test is conducted on concrete specimens on $28^{\text {th }}$ day results are given. The strengths obtained after testing the cubes are:

\begin{tabular}{|c|c|c|c|}
\hline TRAIL & CUBE 1 (N/mm2) & CUBE 2 (N/mm2) & CUBE 3 (N/mm2) \\
\hline 1 & 56.5 & 57.3 & 58.1 \\
\hline 2 & 27 & 29.5 & 29.6 \\
\hline 3 & 27 & 28.5 & 29.4 \\
\hline 4 & 37 & 39.5 & 39.3 \\
\hline 5 & 56 & 52 & 53 \\
\hline 6 & 27.5 & 28 & 26.4 \\
\hline 7 & 27 & 24 & 25.5 \\
\hline 8 & 38 & 39.5 & 34.5 \\
\hline
\end{tabular}

The final results are

NORMAL CONCRETE + 100\% STONE DUST

COMPRESSIVE STRENGTH: $28.7 \mathrm{~N} / \mathrm{mm} 2$

TENSILE STRENGTH: $\quad 2.6 \mathrm{~N} / \mathrm{mm} 2$

SLUMP: $\quad 150 \mathrm{~mm}$

NORMAL CONCRETE + $\mathbf{1 0 0 \%}$ MARBLE SLUDGE

COMPRESSIVE STRENGTH: $38.6 \mathrm{~N} / \mathrm{mm} 2$

TENSILE STRENGTH: $2.84 \mathrm{~N} / \mathrm{mm} 2$

SLUMP: $160 \mathrm{~mm}$

NORMAL CONCTERE + 50\% STONE DUST + 50\% MARBLE SLUDGE

COMPRESSIVE STRENGTH: $57.3 \mathrm{~N} / \mathrm{mm} 2$

TENSILE STRENGTH: $\quad 4.89 \mathrm{~N} / \mathrm{mm} 2$

SLUMP: $146 \mathrm{~mm}$

NOMINAL CONCRETE + 30\% STONE DUST + 70\% MARBLE SLUDGE

COMPRESSIVE STRENGTH: $38.6 \mathrm{~N} / \mathrm{mm} 2$

TENSILE STRENGTH: $3.6 \mathrm{~N} / \mathrm{mm} 2$

SLUMP: $110 \mathrm{~mm}$

CONCRETE WITH 100\% STONE DUST+ 0.71\% OF FIBRE

COMPRESSIVE STRENGTH: $27.3 \mathrm{~N} / \mathrm{mm} 2$

TENSILE STRENGTH: $\quad 3.2 \mathrm{~N} / \mathrm{mm} 2$

SLUMP: $151 \mathrm{~mm}$

CONCRETE WITH 100\% MARBLE SLUDGE+0.71\% OF FIBRE

COMPRESSIVE STRENGTH: $25.5 \mathrm{~N} / \mathrm{mm} 2$

TENSILE STRENGTH: $\quad 3.8 \mathrm{~N} / \mathrm{mm} 2$

SLUMP: $158 \mathrm{~mm}$

CONCRETE WITH 50\% STONE DUST + 50\% MARBLE SLUDGE + $0.71 \%$ FIBRE

COMPRESSIVE STRENGTH: $53.67 \mathrm{~N} / \mathrm{mm} 2$

TENSILE STRENGTH: $5.7 \mathrm{~N} / \mathrm{mm} 2$

SLUMP: $140 \mathrm{~mm}$

CONCRETE WITH 30\% DUST + 70\% MARBLE SLUDGE + 0.71\% FIBRE

COMPRESSIVE STRENGTH: $37.33 \mathrm{~N} / \mathrm{mm} 2$

TENSILE STRENGTH: failed

SLUMP: $115 \mathrm{~mm}$ 


\section{GREEN CONCRETE:}

\begin{tabular}{|c|c|c|c|}
\hline Comparision Set & Compressive strength $(\mathrm{n} / \mathrm{mm} 2)$ & Tensile strength $(\mathrm{n} / \mathrm{mm} 2)$ & Slump $(\mathrm{mm})$ \\
\hline 1 & 57.3 & 4.9 & 150 \\
\hline 2 & 28.7 & 2.6 & 160 \\
\hline 3 & 28.3 & 2.84 & 146 \\
\hline 4 & 38.6 & 3.6 & 110 \\
\hline
\end{tabular}

Fibre reinforced Green concrete:

\begin{tabular}{|l|c|c|c|}
\hline Comparision Set & Compressive strength $(\mathrm{n} / \mathrm{mm} 2)$ & Tensile strength(n/mm2) & Slump(mm) \\
\hline 1 & 53.67 & 5.7 & 151 \\
\hline 2 & 27.3 & 3.2 & 158 \\
\hline 3 & 25.5 & 3.8 & 140 \\
\hline 4 & 37.3 & Failed & 115 \\
\hline
\end{tabular}
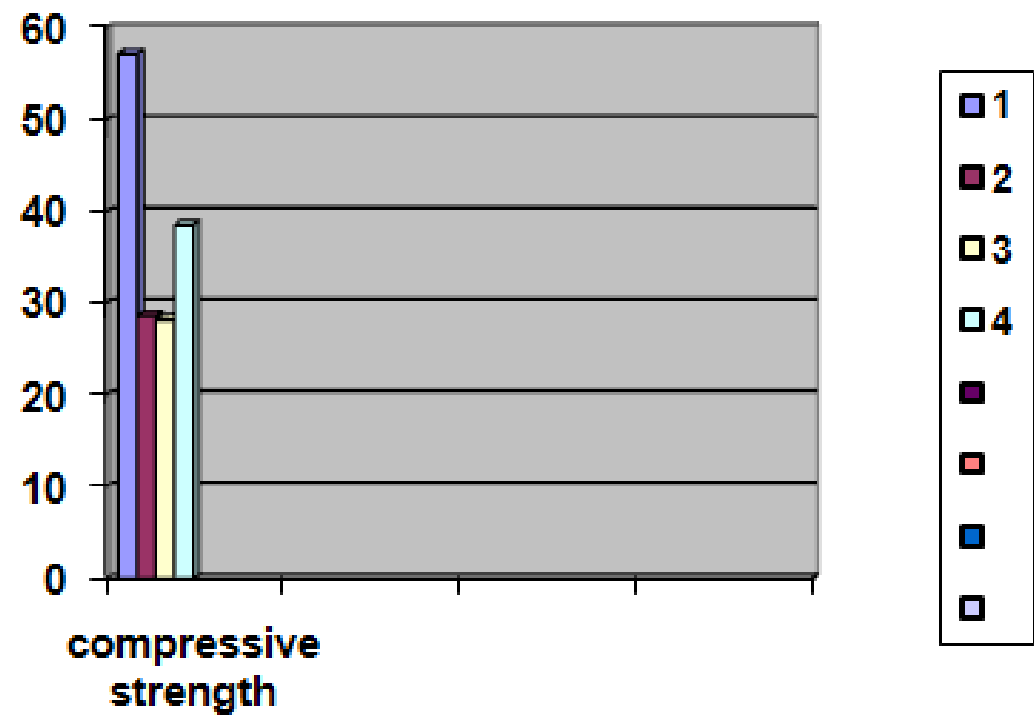

The above graph represents the compressive strengths of 4 cubes without fiber reinforcement

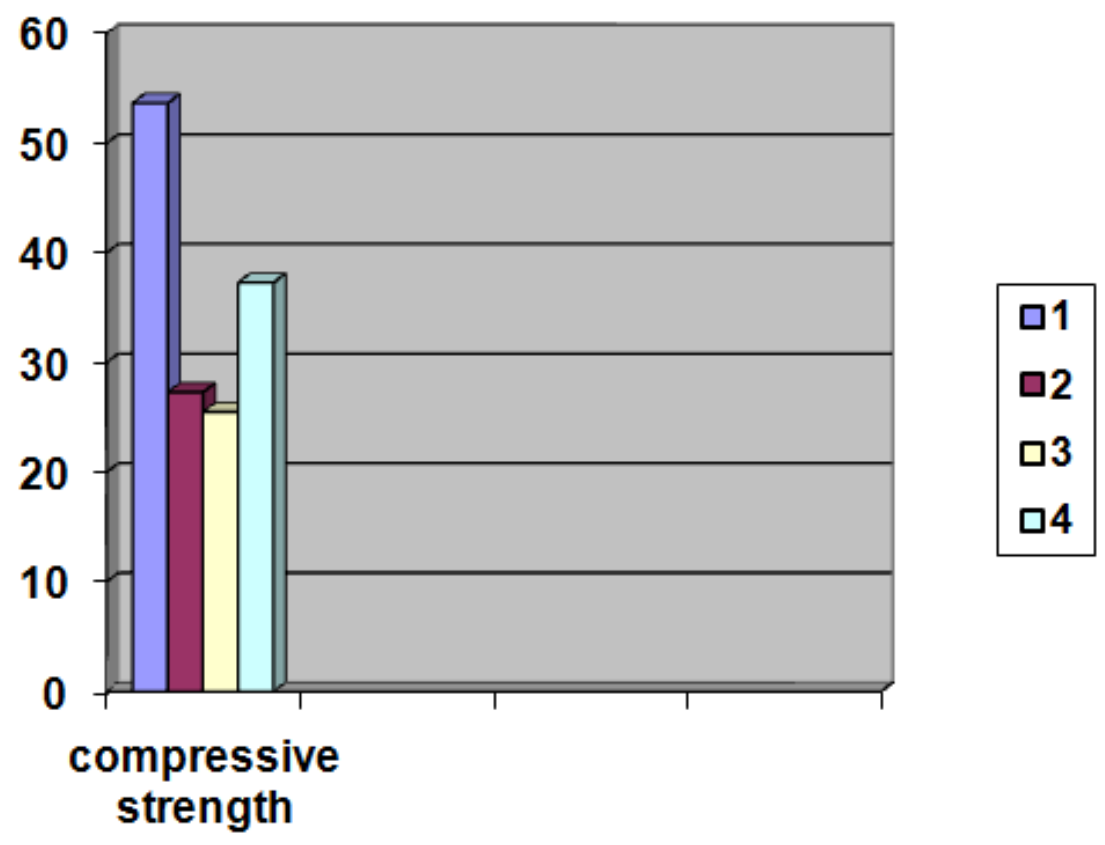

This above graph represents the compressive strengths of 4 different trails after fiber reinforcement. 


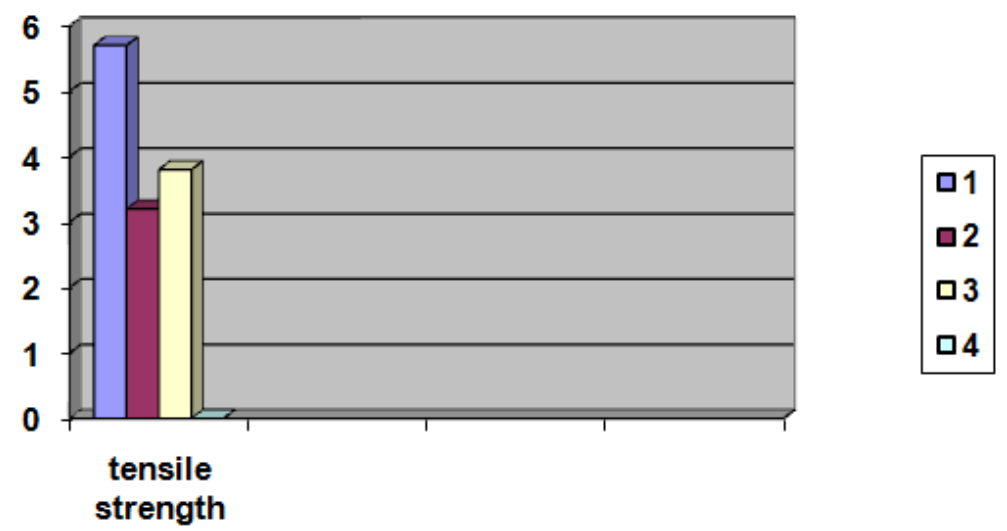

In the above case the last beam has been failed. This is done with fiber reinforcement.

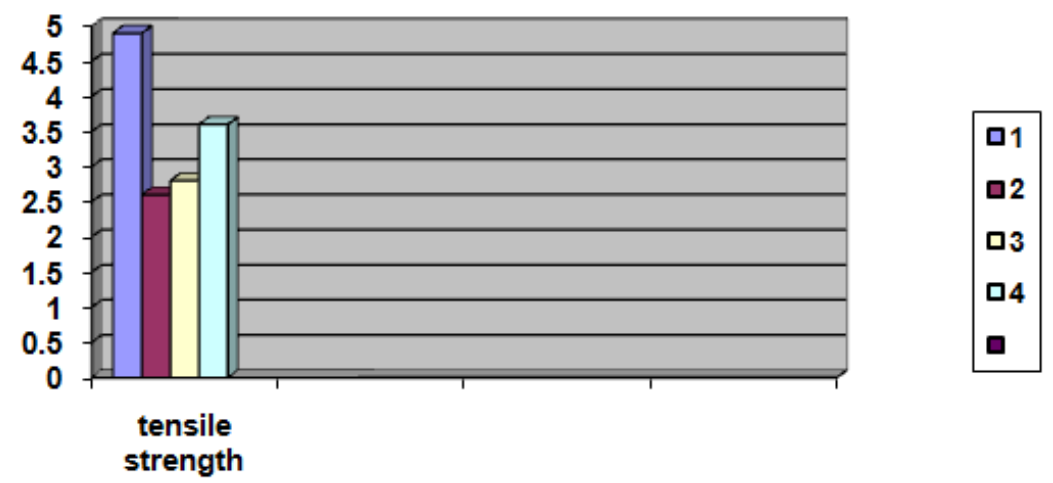

The above graph represents the tensile strengths of beams of 4 trails without fibre reinforcement.

\section{Conclusions}

All the experimental data shows that the addition of industrial wastes improves the physical and mechanical properties. These results are of great importance because this kind of innovative concrete requires large amounts of fine particles. Due to its high fineness of the marble sludge powder it provided to be very effective in assuring very good cohesiveness of concrete

1. The chemical composition of quarry rock dust and marble sludge powder such as fe2o3, mno ,na2o,mgo,k2o and sio 2 are comparable with that of cement.

2. The replacement of fine aggregate with that of marble sludge powder and rock dust in equal proportion of $50 \%$ gives excellent strength. It has high compressive strength ,high split tensile strength. If marble sludge powder content is increased further, it improves workability but affects the compressive and split tensile strengths.

3. Green concrete induced higher workability and it satisfy the self compacting concrete performance which is the slump flow is $657 \mathrm{~mm}$ without affecting the strength of concrete.

4. Water absorption is slightly higher than conventional concrete.

5. Durability is more and permeability is less.

6. It can be used for architectural concrete mixes containing white cement. Thus this green concrete exhibited excellent performance.

7. The bamboo fiber is also a naturally available material everywhere in the world.

8. It is echo friendly product as it is from nature and economical too.

9. It improves tensile strength of the concrete. Drawback is that, compared to steel or other metals it is less durable.

\section{References}

[1]. Siddarth parek.An effort towards protection of ecology and environment and http.//www.cdos-india.com/papers.

[2]. Corinaldesi v., Moriconi, G. and Naik T.R. 20075. CANMET/ACI Three day International Symposium on Sustainable development of cement and concrete, October 5_7,Toronto,CANADA. Characterization of marble dust for its use in motor and concrete.

[3]. Ahmed E.Ahmed and Ahemed A.E. Kourd .1989.properties of concrete incorporating natural and crushed stone very fine sand.ACI Material Journal.86(4):417_424 
[4]. Valeria Corninaldesi, Giacomo Moriconi, and Tarun R.Naik.2005.Characterization of marble powder for its use in mortar and concrete.NMET/ACI International Symposium on sustainable development of cement and concrete, October 5_7,TORONTO,CANADA

[5]. Salih Yazicioglu.2006. physico_chemical treatment of marble processing of waste water and recycling of its sludge. Materials Science and Engineering , Turkey.419(1_2):306_309.

[6]. IS:8112_1989.specification for 43 grade ordinary Portland cement. Bureau of Indian standards, New delhi.

[7]. IS:1199_1959.. Bureau of Indian standards of New delhi. Indian standard methods of sampling and analysis of concrete

[8]. IS:516_1959.Bureau of Indian standards,New delhi. Indain standard methods of test for strength of concrete 